\title{
Study on the possible role of the $-174 G>C$ IL-6 promoter polymorphism in predicting response to rituximab in rheumatoid arthritis*
}

\author{
Studio del possibile ruolo predittivo del polimorfismo $-174 G>C$ \\ del promotore dell'IL-6 nei confronti della risposta al rituximab \\ in corso di artrite reumatoide
}

\author{
M. Fabris ${ }^{1,2}$, L. Quartuccio ${ }^{2}$, S. Lombardi ${ }^{2}$, M. Benucci ${ }^{2}$, M. Manfredi ${ }^{2}$, M. Saracco ${ }^{3}$, F. Atzeni ${ }^{4}$,

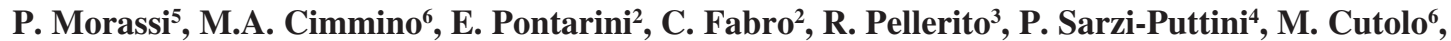 \\ A. Carletto ${ }^{7}$, L.M. Bambara ${ }^{7}$, F. Fischetti ${ }^{5}$, F. Curcio ${ }^{1}$, E. Tonutti ${ }^{8}$, S. De Vita ${ }^{2}$ \\ ${ }^{1}$ Patologia Clinica e Clinica di Reumatologia, Azienda Ospedaliero-Universitaria di Udine, Udine; \\ ${ }^{2}$ Unità di Reumatologia, Ospedale San Giovanni di Dio, Firenze; ${ }^{3}$ Unità di Reumatologia, Ospedale Mauriziano, Torino; \\ ${ }^{4}$ Clinica di Reumatologia, Ospedale L. Sacco, Milano; ${ }^{5}$ Medicina Interna, Ospedali Riuniti di Trieste; \\ ${ }^{6}$ Clinica di Reumatologia, Università di Genova; ${ }^{7}$ Clinica Reumatologica, Università di Verona; \\ ${ }^{8}$ Immunopatologia e Allergologia, Azienda Ospedaliero-Universitaria di Udine,Udine
}

\begin{abstract}
RIASSUNTO
Visto l'elevato costo della terapia con rituximab (RTX), l'identificazione di marcatori biologici predittivi di risposta rappresenta un importante obiettivo. In questo studio è stato analizzato il polimorfismo $-174 G>C$ del promotore dell'IL-6, citochina chiave nella proliferazione B cellulare, quale potenziale marcatore di efficacia del RTX in una coorte "real-life" retrospettiva di 142 pazienti con artrite reumatoide trattati con RTX presso 7 differenti Centri Reumatologici Italiani. La risposta clinica è stata valutata alla fine del sesto mese dopo la prima infusione di RTX utilizzando sia i criteri EULAR (DAS28) chi i criteri ACR. Lo studio ha evidenziato una significativa associazione tra il genotipo -174CC e la non risposta al RTX al mese +6 sia secondo i criteri EULAR, (OR 3,196, 95\% CI=1,204-8,485; $p=0,0234)$, che secondo i criteri ACR. Il polimorfismo $-174 G>C$ dell'IL-6, coinvolto nei meccanismi di regolazione dell'espressione della citochina, appare pertanto un nuovo possibile marcatore in grado di identificare i pazienti con $A R$ ad elevato rischio di non risposta al RTX.
\end{abstract}

Reumatismo, 2010; 62(4):253-258

\section{INTRODUCTION}

S eve everal studies demonstrated the efficacy of the B-cell depletion therapy with rituximab (RTX) in RA patients, including those unresponsive to anti-TNF therapy, underlying the important role of B cells in this disease (1-5). Several recent papers

*Lavoro premiato al XLVI Congresso SIR, Rimini 2009.

Indirizzo per la corrispondenza:

Martina Fabris, MD

Clinical Pathology and Clinic of Rheumatology

Azienda Ospedaliero-Universitaria of Udine

Piazzale Santa Maria Misericordia

33100 Udine, Italy

E-mail: fabris.martina@aoud.sanita.fvg.it have demonstrated a differential effects of RTX in depleting B-cells and blocking plasma cell generation at the synovial and at the bone marrow level (7-9). This differential effect may explain why among patients who respond to RTX, some relapse while others show a very prolonged response, independently from the reappearance of B-cells in the peripheral blood (6). However, the efficacy of RTX may also depend on the individual genetic predisposition. At this regard, very few data were produced by now.

IL-6 is a key cytokine in RA pathogenesis, driving both the systemic inflammation and the synovial joint destruction, as proved by the important results of the anti-IL-6 therapy in RA patients (10, 11). Furthermore, IL-6 has a fundamental role in 
B cell survival and proliferation (12), and then its expression may be involved in RTX efficacy.

IL-6 exerts its biological activities through interaction with its specific receptor called gp80 or IL$6 \mathrm{R}$ alpha on the surface of target cells. The IL6/IL-6R alpha complex recruits two signal-transducing beta gp130 subunits, leading to the formation of the high-affinity IL-6 receptor complex and finally to signal transduction $(13,14)$. The IL6R alpha and beta exist also as soluble forms are generated by either proteolytic cleavage of their membrane moiety or by alternative splicing. The association of IL-6 with the soluble form of IL-6R alpha is capable of eliciting a biological response in cells that express only the membrane gp130. This type of activation, called "trans-signalling", renders virtually all cells capable of responding to IL6/sIL-6R alpha complexes $(15,16)$. Different IL-6 or soluble IL-6R alpha (sIL-6Ra) levels have been described due to specific polymorphisms in IL-6 and IL-6R genes (17-22). We here investigated a possible association between RA response to RTX and the $-174 \mathrm{G}>\mathrm{C}$ IL-6, previously associated with different IL-6 serum levels in RA patients (17).

\section{PATIENTS AND METHODS}

\section{Patients}

The study was conducted in a real-life retrospective cohort of 142 unselected patients (120 females and 22 males; mean age $60.2 \pm 12.9$ years) with RA diagnosed according to the ACR classification criteria (23). The disease duration was $13.9 \pm 10$ years. All patients gave their informed consent to the study according to the Declaration of Helsinki and the investigation was approved by the local Study Review Board. Patients were referred to seven different rheumatologic Centres in the North of Italy. One hundred and thirteen $(79.6 \%)$ patients were rheumatoid factor (RF)-positive and 112 (78.9\%) were anti-CCP antibodies positive. All patients were treated with RTX intravenous infusions (500 $\mathrm{mg}$ at weeks $0,1,2,3$ or $1,000 \mathrm{mg}$ at weeks 0,2 ) in monotherapy ( 9 cases) or in combination with methotrexate (MTX) (124 cases) or other disease modifying anti-rheumatic drugs (DMARDs: leflunomide, cyclosporin A or hydroxychloroquine; 9 cases). One hundred and four $(73.2 \%)$ patients had been previously treated with one or more anti-TNF agents. Thirty-eight patients did not experience any biologic therapy before RTX, but were unresponsive to MTX alone or in combina- tion with other DMARDs for at least 6 months. The efficacy of RTX was evaluated at the end of the sixth month after the first RTX infusion, using both the European League Against Rheumatisms (EULAR) response criteria, (mean baseline DAS28 6.17 \pm 1.11 , range 3.00-8.52) and the American College of Rheumatology (ACR) response criteria (considering responder patients when $\mathrm{ACR} \geq 50$ ).

\section{Genetic analyses}

DNA was extracted by EDTA-treated peripheral blood using an automated methodology (Maxwell 16, Promega, Madison, WI, USA) and dedicated kits (Maxwell 16 Blood DNA purification kit). The analysis of the $-174 \mathrm{G}>\mathrm{C}$ IL-6 promoter polymorphism was made following previously reported methods (19). Briefly, the followings forward and reverse primers were used: 5'-TGACTTCAGCTTTACTCTTGT-3' and 5'-CTGATTGGAAACCTTATTAAG-3'; in a PCR amplification protocol comprising 39 cycles composed by the following 3 steps: 1 minute at $95^{\circ} \mathrm{C}, 1$ minute at $55^{\circ} \mathrm{C}, 1$ minute at $72^{\circ} \mathrm{C}$. PCR products were finally digested with NlaIII (New England Biolabs) and run onto a $3.5 \%$ ethidium bromide-stained agarose gel.

\section{Statistical analyses}

Chi-square tests for categorical variables and nonparametric $t$ tests for quantitative variables were used using the GraphPad and InStat softwares. Results were considered statistically significant for $\mathrm{p} \leq 0.05$.

\section{RESULTS}

\section{Response to $R T X$ at month +6 in the population under study}

As illustrated in figure 1, a great concordance was found between the EULAR and ACR response criteria. By EULAR criteria 30/142 (21.1\%) patients were good responders, 80/142 (56.3\%) moderate responders and 32/142 (22.5\%) non responders (NR). By the ACR response criteria, 91/142 (64.1\%) disclosed a major response (26 ACR70/90 patients plus 65 ACR50 patients), while 51/142 (35.9\%) were considered non responders (comprising 26 ACR20 patients and 25 null responder patients).

\section{Prevalence of the $-174 G>C$ IL-6 genotypes in the population under study}

The prevalence of the IL- $6-174 \mathrm{G}>\mathrm{C}$ genotypes in 


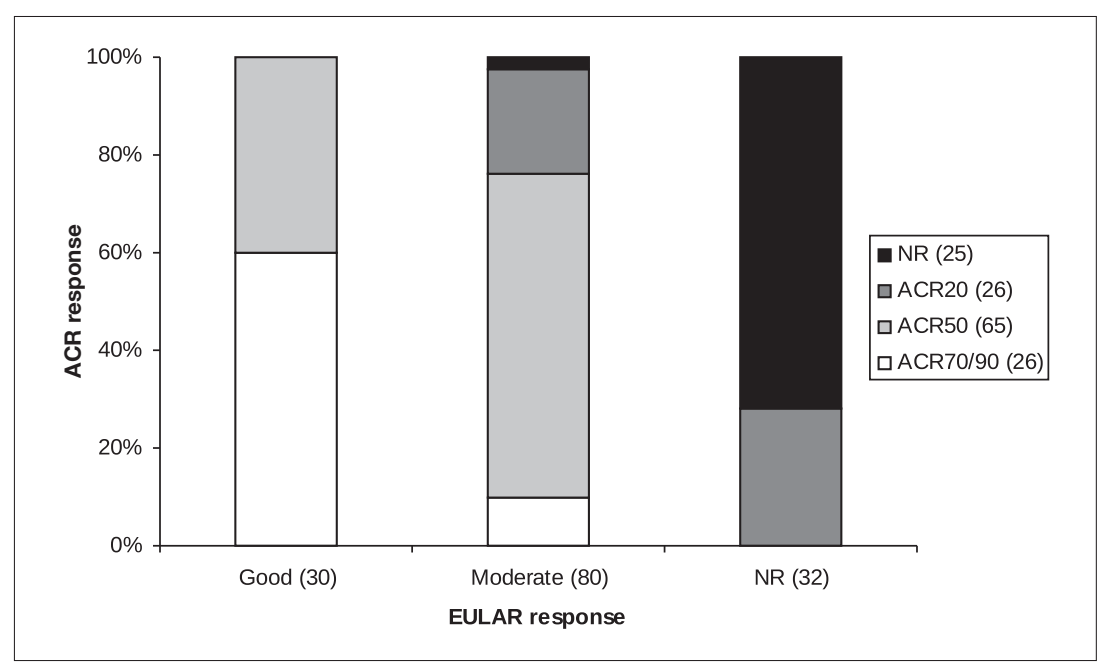

Figure 1 - Concordance between EULAR (X-axis) and ACR (Y-axis) criteria for the evaluation of response to RTX in the studied population.

the present RA series (GG: 42.3\%, GC: $42.9 \%$, and CC: $14.8 \%$ ) was comparable to the prevalence already published in other Caucasian RA series $(17,21,22)$. No significant difference in genotype distribution was found with respect to patient age, sex, disease duration, baseline DAS28, C-reactive protein (CRP), health assessment questionnaire (HAQ), RF and anti-CCP antibodies status, and the number of previously failed anti-TNF agents.

\section{No response to $R T X$ at month +6 is associated with the IL-6 -174 CC homozygosis}

As illustrated in figure 2, GG and GC patients disclosed the same IL-6 genotype distribution according to the degree of response to RTX. Thus they were pooled together and compared to the CC patients: no response to RTX at month +6 by EULAR criteria resulted more prevalent in the IL- 6 174 CC RA patients $(9 / 21,42.8 \%)$, than in the GC/GG patients $(23 / 121,19 \%)$ (OR 3.196, 95\% $\mathrm{CI}=1.204-8.485 ; \mathrm{p}=0.0234)$. Moreover, a EULAR good response was present only in $1 / 21(4.8 \%)$ of the CC patients versus $29 / 121,23.9 \%$ of the GG/GC patients (OR 0.159; $95 \% \mathrm{CI}=0.0204$ 1.234; $\mathrm{p}=0.0471$ ). Similar results were found when considering the ACR response criteria, since a poor response ( $\leq$ ACR50) to RTX was present in $12 / 21$ $(57.1 \%)$ of CC cases versus 39/121 $(32.2 \%)$ of $\mathrm{GG} / \mathrm{GC}$ cases $(\mathrm{OR}=2.803,95 \% \mathrm{CI}=1.090-7.212$; $\mathrm{p}=0.0465$ ). Of note, the ACR70/90 response was present in $1 / 21(4.8 \%)$ of CC cases versus $25 / 121$ (20.7\%) of GG/GC cases (OR 0.192; p=ns).

As previously demonstrated (24), a significant association between positive RF and response to RTX was also found in the present RA series: a positive response to RTX by EULAR criteria at month +6

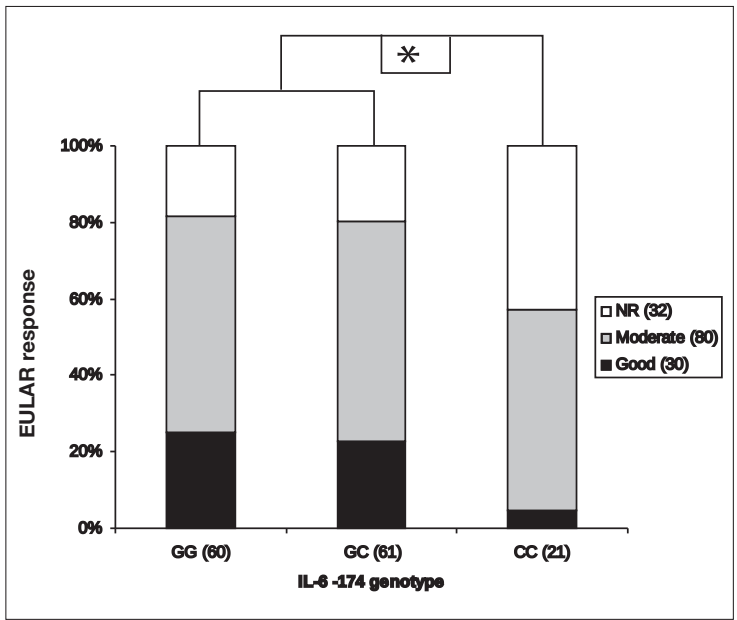

Figure 2 - The relationship between response to RTX at month +6 and the IL-6 -174G>C polymorphism. The prevalence of the lack of response to RTX by EULAR criteria was significantly higher in the IL-6 -174 CC RA patients $(9 / 21,42.8 \%)$, compared to the GC/GG patients $(23 / 121,19 \%)$, *(OR 3.196, 95\% Cl=1.204-8.485; $\mathrm{p}=0.0234)$.

was present in 94/113 (83.2\%) of RF-positive RA patients versus $16 / 29(55.2 \%)$ of the RF-negative RA patients $(\mathrm{OR}=4.020,95 \% \mathrm{CI}=1.663-9.717$; $\mathrm{p}=0.0025)$. The same results were obtained when evaluating the response to RTX by ACR criteria (data not shown).

\section{DISCUSSION}

The list of the biologic agents available for RA treatment is continuing growing, but the cost of these drugs are still elevated, thus the identification of biomarkers able to predict response to each spe- 
cific therapeutic agent is of high priority and represent also an intriguing challenge for the scientific community.

RTX has proved of great efficacy in RA but, as in the case of other biologic agents, response may vary between patients, based also on genetic background. High serum levels of IL-6 are directly correlated with disease activity, RF production, leukocyte infiltration, the severity of joint damage and the systemic manifestations of RA $(12,25)$ and IL6 directly favours B cell survival and proliferation, being the most abundant cytokine in the rheumatoid synovium. Recently a significant decrease of IL-6 levels were described in the follow-up of RA patients who respond to RTX (26), but no baseline biological markers were identified to date. In the present study we have shown a significant correlation between the $-174 \mathrm{G}>\mathrm{C}$ IL-6 promoter polymorphism, linked to IL-6 expression level, and response to RTX in RA patients, with comparable results when evaluating the response either by the EULAR and by the ACR criteria.

In accordance with previous studies $(24,27)$, positive RF again appeared as a strong positive predictive marker of response to RTX, and this result reinforce those found about the genetic association here observed.

Therefore, the analysis of the $-174 \mathrm{G}>\mathrm{C}$ IL- 6 promoter polymorphism may be relevant in the evaluation of the RA patient for the choice of RTX therapy.

The main goal of RA therapy is to achieve a good response, instead of a moderate one. In our series, patients carrying the IL6 -174CC homozygosis were very rarely EULAR good responders, if compared to CG/GG - carrying patients $(4.8 \%$ versus $23.9 \%$ ), while moderate response was similar in the 2 groups ( $52.4 \%$ and $57 \%$, respectively). Then, based on the present results, a good response to RTX appears very unlikely in patients with RA showing the IL6 -14 CC genotype and thus, treatments different from RTX might be then considered in these patients. Anyway, larger replication studies are needed and still planned by our group to confirm present results. Of note, the same association between poor response to RTX and the IL6 -174CC homozygosis was seen in the present RA series when subdividing patients as coming from
Eastern or Western areas of north Italy (data not shown).

Within-population differences in IL-6 concentration are due both to genetic and environmental influences. Several papers deal with the genetic regulation of IL-6 promoter, and IL-6 gene expression regulation appeared to be affected by complex haplotypes comprising several gene polymorphisms (28). The $-174 \mathrm{G}>\mathrm{C}$ polymorphism appears as one major determinant and, recently, a large British study on 383 RA patients demonstrated higher IL6 serum levels in patients with the IL-6 -174CC homozygosis, who were more prone to develop cardiovascular complications (17).

According to these findings, the presence of higher IL-6 serum levels linked to the CC homozygosis of the $-174 \mathrm{G}>\mathrm{C}$ IL-6 polymorphism associate with a poor RTX response in RA.

However, when different cytokines were analysed at baseline and in the follow-up of RA patients treated with RTX, no predictive baseline profile was discovered, while a significant decrease of IL6 and CRP levels was found in patients showing a better response (26). The decreased IL-6 expression following RTX therapy, rather than the baseline levels, may relate to the degree of response, and serum IL- 6 at baseline did not seem to represent a useful tool to predict response to RTX (26). It is widely known that several unpredictable variables (concomitant drug therapy, concomitant infections, endocrine factors, etc) may affect IL-6 serum levels. Thus, the genetic approach, as we here investigated, should be a more reliable indicator of IL-6 activity.

Currently, very few data are available about genetic markers useful, at baseline, to better guide the choice of RTX therapy in RA. We herein provide preliminary evidence of a new possible genetic marker, the CC homozygosis of the -174 IL-6 promoter polymorphism, as a predictor of no response to RTX in RA. This preliminary evidence, if confirmed, may be relevant to optimize the treatment of RA with RTX and other biologic agents $(6,10,29)$.

\section{Ringraziamenti}

Il lavoro è stato supportato dai fondi del finanziamento della Regione Friuli Venezia Giulia, (LR 26.05.07/art. 23). 


\section{SUMMARY}

Objective. Identification of genetic biomarkers of response to biologics in rheumatoid arthritis (RA) is a relevant issue. The -174G>C interleukin-6 (IL-6) promoter polymorphism was investigated in RA patients treated with rituximab (RTX), being IL-6 a key cytokine for B cell survival and proliferation, thus possibly implicated in rituximab efficacy. Methods. The study was conducted in a real-life retrospective cohort of 142 unselected RA patients (120F/22M) treated with RTX and referred to 7 rheumatologic centres in the north of Italy. One hundred and thirteen (79.6\%) patients were rheumatoid factor (RF)-positive and $112(78.9 \%)$ were anti-CCP antibodies positive. The response to therapy was evaluated at the end of the sixth month after the first RTX infusion, by using both the EULAR criteria (DAS28) and the ACR criteria. The IL-6 -174G >C promoter polymorphism was analyzed by RFLP following previously reported methods.

Results. Lack of response to RTX at month +6 by EULAR criteria was more prevalent in RA patients with the IL- 6 174 CC genotypes $(9 / 21,42.8 \%)$, than in the GC/GG patients $(23 / 121,19.0 \%)(\mathrm{OR} 3.196,95 \%$ CI=1.204-8.485; $\mathrm{p}=0.0234)$. Similar results were found when evaluating the response by ACR criteria. No differences were found in RA duration, baseline DAS28, baseline HAQ, RF status, anti-CCP status according to the different IL-6 -174 genotypes.

Conclusion. IL-6 promoter genotyping may be useful to better plan treatment with RTX in RA. Larger replication studies are in course to confirm these preliminary results.

Parole chiave - IL-6, farmacogenetica, rituximab, artrite reumatoide.

Key words - IL-6, pharmacogenetics, rituximab, rheumatoid arthritis.

\section{REFERENCES}

1. Reff ME, Carner K, Chambers KS, Chinn PC, Leonard JE, Raab R, et al. Depletion of B cells in vivo by chimeric mouse human monoclonal antibody to CD20. Blood 1994; 83: 435-45.

2. Edwards JC, Szczepanski L, Szechinski J, FilipowiczSosnowska A, Emery P, Close DR, et al. Efficacy of Bcell-targeted therapy with rituximab in patients with rheumatoid arthritis. N Engl J Med 2004; 350: 2572-81.

3. De Vita S, Zaja F, Sacco S, De Candia A, Fanin R, Ferraccioli G. Efficacy of selective B cell blockade in the treatment of rheumatoid arthritis: evidence for a pathogenetic role of B cells. Arthritis Rheum 2002; 46: 2029-33.

4. Cohen SB, Emery P, Greenwald MW, Dougados M, Furie RA, Genovese MC, et al. REFLEX Trial Group. Rituximab for rheumatoid arthritis refractory to anti-tumor necrosis factor therapy: Results of a multicenter, randomized, double-blind, placebo-controlled, phase III trial evaluating primary efficacy and safety at twenty-four weeks. Arthritis Rheum 2006; 54: 2793-806.

5. De Vita S, Quartuccio L. Treatment of rheumatoid arthritis with rituximab: an update and possible indications. Autoimmun Rev 2006; 5: 443-8.

6. Dörner T, Burmester GR. New approaches of B-celldirected therapy: beyond rituximab. Curr Opin Rheumatol 2008; 20: 263-8.

7. Thurlings RM, Vos K, Wijbrandts CA, Zwinderman AH, Gerlag DM, Tak PP. Synovial tissue response to rituximab: mechanism of action and identification of biomarkers of response. Ann Rheum Dis 2008; 67: 917-25.

8. Teng YK, Levarht EW, Hashemi M, Bajema IM, Toes RE, Huizinga TW, et al. Immunohistochemical analysis as a means to predict responsiveness to rituximab treatment. Arthritis Rheum 2007; 56: 3909-18.
9. Vos K, Thurlings RM, Wijbrandts CA, van Schaardenburg D, Gerlag DM, Tak PP. Early effects of rituximab on the synovial cell infiltrate in patients with rheumatoid arthritis. Arthritis Rheum 2007; 56: 772-8.

10. Dayer JM, Choy E. Therapeutic targets in rheumatoid arthritis: the interleukin-6 receptor. Rheumatology (Oxford) $2010 ; 49: 15-24$.

11. Mima T, Nishimoto N. Clinical value of blocking IL6 receptor. Curr Opin Rheumatol 2009; 21: 224-30.

12. Fonseca JE, Santos MJ, Canhão H, Choy E. Interleukin-6 as a key player in systemic inflammation and joint destruction. Autoimmun Rev 2009; 8: 538-42.

13. Kishimoto T. Interleukin-6: discovery of a pleiotropic cytokine. Arthritis Res Ther 2006;8 (Suppl. 2): S2.

14. Rose-John S, Scheller J, Elson G, Jones SA. Interleukin- 6 biology is coordinated by membrane-bound and soluble receptors: role in inflammation and cancer. $\mathrm{J}$ Leukoc Biol 2006; 80: 227-36.

15. Kallen KJ. The role of transsignalling via the agonistic soluble IL-6 receptor in human diseases. Biochim Biophys Acta 2002; 1592: 323-43.

16. Jones SA, Richards PJ, Scheller J, Rose-John S. IL-6 transsignaling: the in vivo consequences. J Interferon Cytokine Res 2005; 25: 241-53.

17. Panoulas VF, Stavropoulos-Kalinoglou A, Metsios GS, Smith JP, Milionis HJ, Douglas KM, et al. Association of interleukin-6 (IL-6)-174G/C gene polymorphism with cardiovascular disease in patients with rheumatoid arthritis: the role of obesity and smoking. Atherosclerosis 2009; 204: 178-83.

18. Smith AJP, Humphries SE. Cytokine and cytokine receptor gene polymorphisms and their functionality. Citokyne Growth Factor Rev 2009; 20: 43-59.

19. Fishman D, Faulds G, Jeffery R, Mohamed-Ali V, Yudkin JS, Humphries S, et al. The effect of novel polymorphisms in the interleukin-6 (IL-6) gene on IL-6 
transcription and plasma IL-6 levels, and an association with systemic-onset juvenile chronic arthritis. J Clin Invest 1998; 102: 1369-76.

20. Esteve E, Villuendas G, Mallolas J, Vendrell J, LópezBermejo A, Rodríguez M, et al. Polymorphisms in the interleukin-6 receptor gene are associated with body mass index and with characteristics of the metabolic syndrome. Clin Endocrinol (Oxf) 2006; 65: 88-91.

21. Smith AJ, D'Aiuto F, Palmen J, Cooper JA, Samuel J, Thompson S, et al. Association of serum interleukin-6 concentration with a functional IL6 -6331T >C polymorphism. Clin Chem 2008; 54: 841-50.

22. Pascual M, Nieto A, Matarán L, Balsa A, Pascual-Salcedo D, Martín J. IL-6 promoter polymorphisms in rheumatoid arthritis. Genes Immun 2000; 1: 338-40.

23. Arnett FC, Edworthy SM, Bloch DA, McShane DJ, Fries JF, Cooper NS, et al. The American Rheumatism Association 1987 revised criteria for the classification of rheumatoid arthritis. Arthritis Rheum 1988; 31: 315-24.

24. Quartuccio L, Fabris M, Salvin S, Atzeni F, Saracco M, Benucci M, et al. Rheumatoid factor positivity rather than anti-CCP positivity, a lower disability and a lower number of anti-TNF agents failed are associated with response to rituximab in rheumatoid arthritis. Rheumatology (Oxford) 2009; 48: 1557-9.

25. Yoshizaki K, Nishimoto N, Mihara M, Kishimoto T. Therapy of rheumatoid arthritis by blocking IL-6 signal transduction with a humanized anti-IL-6 receptor antibody. Springer Semin Immunopathol 1998; 20: 247-59.

26. Fabre S, Guisset C, Tatem L, Dossat N, Dupuy AM, Cohen JD, et al. Protein biochip array technology to monitor rituximab in rheumatoid arthritis. Clin Exp Immunol 2009; 155: 395-402.

27. van Vollenhoven RF, Chatzidionysiou K, Gabay C. Rheumatoid factor predicts response to rituximab in a European registry-based cohort: 6-month results from the collaborative European registries for rituximab in rheumatoid arthritis (CERERRA). Ann Rheum Dis 2009; 68 (Suppl. 3): 579.

28. Reich D, Patterson N, Ramesh V, De Jager PL, McDonald GJ, Tandon A, et al. Admixture mapping of an allele affecting interleukin 6 soluble receptor and interleukin 6 levels.; Health, Aging and Body Composition (Health ABC) Study. Am J Hum Genet 2007; 80: 716-26.

29. Buch MH. Sequential use of biologic therapy in rheumatoid arthritis. Curr Opin Rheumatol 2010; 22: 321-9. 